Geological Significance of their Distribution. Proc. Malacol. Soc. London 18:165-209, pls. 11-13.

Eames, F. E., and L. R. Cox. 1956. Some Tertiary Pectinacea from East Africa, Persia, and the Mediterranean Region. Proc, Malacol. Soc. London 32:1-68, 20 pls.

Emerson, W. K. 1965. Strombus (Tricornis) oldi New Species. Indo-Pacific Mollusca 1(6):397-398, pl. 294.

Gruffydd, Ll. D. 1981. Observations on the Rate of Production of External Ridges on the Shell of Pecten maximus in the Laboratory. Jour. Marine Biol. Ass. U.K. 61:401-411.

Helm, N. E., and R. E. Malouf. 1983. Rate of Production of External Ridges in the Bay Scallop, Argopecten irradians. (Abstract) Amer. Zoologist 23(4):1024.

Jones, D. S. 1981. Repeating Layers in the Molluscan Shell Are Not Always Periodic. Jour. Paleo. 55(5):1076-1082.

Matsukuma, Akihiko. 1978. Fossil Boreholes Made by ShellBoring Predators or Commensals. I. Boreholes of Capulid Gastropods. Japanese Jour. Malacol. (Venus) 37(1):29-45.

Ohno, Terufumi, 1985. Experimentelle Analysen zur Rhythmik des Schalenwachstums einiger Bivalven und ihre Paläobiologische Bedeutung. (Experimental
Analyses Concerning the Rhythm of Shell Growth in some Bivalves and its Paleobiological Implications). Palaeontographica, Abt. A, 289:63-123, 7 pls.

Orr, Virginia. 1962. The Drilling Habit or Capulus daniel (Crosse) (Mollusca: Gastropoda). The Veliger 5(2):63-67, pl. 7.

Waller, T. R. 1969. The Evolution of the Argopecten gibbus Stock (Mollusca: Bivalvia), with Emphasis on the Tertiary and Quaternary Species of Eastern North America. Paleont. Soc. Mem. 3 (Jour. Paleo., 43(5), suppl.), 125 p., 7 pls.

1972. The Pectinidae (Mollusca: Bivalvia) of Eniwetok Atoll, Marshall Islands. The Veliger 14(3): 221-264, 8 pls.

1978. Morphology, Morphoclines and a New Classification of the Pteriomorphia (Mollusca: Bivalvia). Phil. Trans. Royal Soc. London, B, 284:345-365. 1984. The Ctenolium of Scallop Shells: Functional Morphology and Evolution of a Key Family-level Character in the Pectinacea (Mollusea: Bivalvia). Malacologia 25(1):203-219

\title{
A NEW SPECIES OF TRITONIA (NUDIBRANCHIA) FROM SOUTHERN CALIFORNIA AND BAJA CALIFORNIA
}

\author{
Hans Bertsch \\ Biological Sciences, National University, Los Angeles, CA
}

and

Antonio Mozqueira Osuna

Escuela Superior de Acuacultura, Centro de Estudios Superiores del Estado de Sonora (CESUES), Navojoa, Sonora, Mexico

\begin{abstract}
Tritonia myrakeenae is described as a new species from the Californian marine faunal province and is distinguished anatomically from the north Pacific and north Atlantic species of Tritonia.
\end{abstract}

Although the opisthobranch gastropod fauna of the northeastern Pacific has been monographed extensively by numerous authors (e.g., recently by Marcus, 1961 a; MacFarland, 1966; Keen, 1971; McDonald, 1983; et al.), there are still numerous new distributional records (e.g., Bertsch, 1981; Behrens, 1982; Gosliner \& Millen, 1984) and new species descriptions (e.g.,

'Mailing address: 6056 Beeman Ave., No. Hollywood, CA 91606
Gosliner, 1981; Behrens, 1984; and Millen, 1985) being published. These add significantly to the known species of opisthobranchs that are endemic to this coastline or its various marine faunal provinces, or that are shared with other marine zoogeographic regions. In this paper we describe a new species of Tritonia that occurs in the Californian marine faunal province; the existence of this species was first reported over 5 years ago (Behrens, 1980). 


\section{Order Nudibranchia Suborder Dendronotacea Family Tritoniidae Lamarck, 1809}

Tritonia myrakeenae Bertsch \& Mozqueira, n. sp.

Synonymy: Tritonia sp. Behrens, 1980: 102-103 (includes a color photograph of the living animal).

Type Locality: Southeast end of Isla Cedros, Baja California, Mexico, rocky reef west of lighthouse, in Bahía Sudeste: $28^{\circ} 2^{\prime} 30^{\prime \prime} \mathrm{N}$; $115^{\circ} 12^{\prime} \mathrm{W}$.

Type Material: Holotype: Approximately 7 $\mathrm{mm}$ long while alive, $4.5 \mathrm{~mm}$ preserved; intertidal zone, rocky reef SE end of Isla Cedros; leg. H. Bertsch and Soa Tsung, 26 December 1985. Deposited in the collection of the Los Angeles County Museum of Natural History, Dept. of Malacology, No. LACM 2135.

Paratype: Approximately $6 \mathrm{~mm}$ long while alive, $4 \mathrm{~mm}$ preserved; intertidal zone, rocky reef SE end of Isla Cedros; leg. H. Bertsch and Soa Tsung, 26 December 1985. Deposited in the collection of Los Angeles County Museum of Natural History, Dept. of Malacology, No. LACM 2136.

Paratypes: Three specimens, 3.5, 4, and 4.5 $\mathrm{mm}$ preserved lengths; intertidal zone in front of Hotel Puesta del Sol, El Sauzal, approximately $8 \mathrm{~km}$ north of Ensenada, Baja California, Mexico $\left(31^{\circ} 52^{\prime} \mathrm{N} ; 116^{\circ} 41^{\prime} \mathrm{W}\right)$; leg. A. Mozqueira, September 1984. Deposited in the collections of California Academy of Sciences, Dept. of Invertebrate Zoology, No. CASIZ 061379.

Additional Records and Range: The authors and Jesus Pineda have found specimens infrequently in the intertidal region at El Sauzal (in front of Hotel Puesta del Sol), Baja California, during June, September, October and November 1983, and February and March 1984. Behrens (1980: 102) reported the occurrence of Tritonia myrakeenae (as Tritonia sp.) from "Santa Barbara to San Diego, California." All known records of this species are only from the intertidal region. At this time, the known range of Tritonia myrakeenae is from Santa Barbara, southern California, U.S.A., to the SE tip of Isla Cedros, near the southern limit of the state of Baja California, Mexico.

Description: A thin, elongate, delicate- appearing tritoniid, $6-18 \mathrm{~mm}$ in total length (alive). Oral veil with 4-7 (rarely branching) tentacular processes. Foot broadly expanded laterally beyond sides of body; anterior margin gently rounded, bilabiate; posteriorly extending out flat past the body, terminating in a pointed tip. Retractile rhinophores surrounded by basal sheath; the rhinophore stalk bears $10-22$ vertical processes which encircle the shaft below the tip. Dorso-lateral edge with a delicate, undulating free margin from which grow the branchial processes (often 9 on each side). Each branchial appendage branches distally into 3-5 filaments.

Color a very pale dirty orange-brown (see color photo in Behrens, 1980: 103); oral veil and sides of foot clear of color, partly opaque. Distinctive white patches occur on the dorsum (often as a matched pair on each side of the midline); Behrens (1980: 103) illustrates an animal with 4 transverse groups of opaque white patches (or streaks) arranged down the length of the back. Specimens from Ensenada and Isla Cedros (Figure 1) had fewer white splotches (usually just a pair located about $1 / 3$ of the body length distant from the anterior end).

Radula (Figure 2A) about $1.1 \mathrm{~mm}$ long, 0.65 $\mathrm{mm}$ across at widest portion. Radular formulae of 2 specimens collected 26 September 1983 at El Sauzal were: $22(10.1 .1 .1 .10)$ and 25 (8-10.1.1.1.8-10) (widest row damaged but appeared to have 12 outer lateral teeth). Central rachidian tooth prominent (approximately 63 microns wide), with 3 posteriorly-directed cusps (Figures 2B and 3B). First lateral tooth well differentiated from the others, its structure a hooklike cusp curling over the side of the rachidian (Figures 2B and 3B). Succeeding laterals all fairly straight, blade-like cusps.

Jaws elongate (Figure 3A), each about $1.3 \mathrm{~mm}$ long and $0.37 \mathrm{~mm}$ wide; a row of pointed mam-

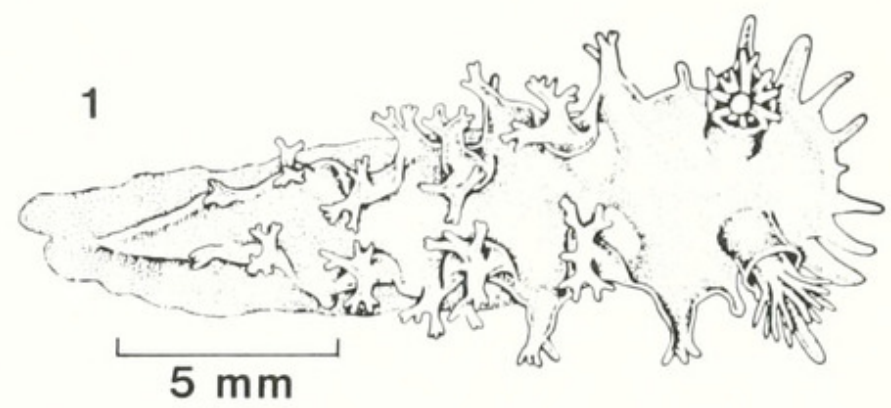

FIG. 1. Tritonia myrakeenae, spec now, dorsal view of living animal. Drawing by C. Yañes. 


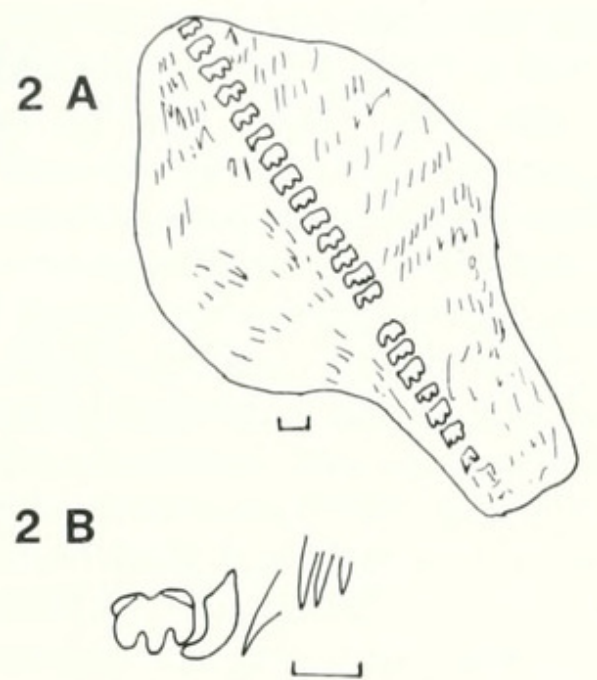

FIG. 2. Camera lucida drawings (scale represents $50 \mu$ ) of: $2 \mathrm{~A}$. Major shape and features of entire radula, and 2B. Rachidian tooth, innermost lateral, and four outer lateral teeth of Tritonia myrakeenae.

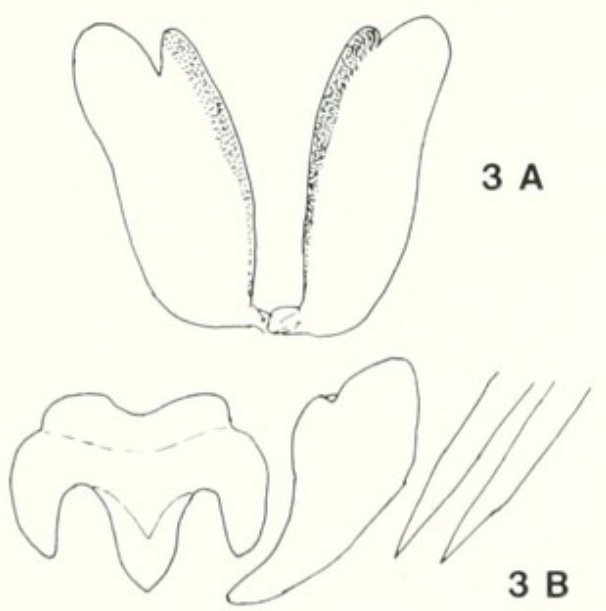

FIG. 3. Tritonia myrakeenae, sketches of jaws (3A) and selected radular teeth $(3 \mathrm{~B}$, rachidian, innermost lateral tooth, and two outer lateral teeth).

millate denticles begins on the inner margin at the joined region of the jaws, continuing as a row along the entire inner edge, increasing about $1 / 3$ of the length to $3-5$ rows; the inner denticled margin terminates distally in a small blunt process or free flange.

Discussion: Tritonia myrakeenae is readily distinguished from other north Pacific species of Tritonia. Tritonia hawaiiensis Pease, 1860, has much more prominent and more highly branched branchial processes and tints of orange-pink and dirty light-purple (Bertsch \& Johnson, 1981: 84-85) which are absent in our new species. Tritonia insulae (Baba, 1955) has vermilion-tinted gills and a different radular formula: 30 (40-46.1.1.1.40-46). Tritonia diomedea Bergh, 1894, has a distinct white line bordering the edge of the foot, and a larger radular formula. Tritonia festiva (Stearns, 1873) has a series of white lines and loops reticulating on the dorsum and a radula with more teeth in each row. Tritonia pickensi Marcus \& Marcus, 1967, has a distinct white swath running down the center of the dorsum with lateral extensions to the branchial processes; although it has a similar radular formula, the shape of the rachidian tooth (narrower and deeper indentation between the cusps) and the presence of small denticles on the cusp of the first lateral tooth (Bertsch \& Gosliner, 1984) are differentiating features.

Species of Tritonia in the North Atlantic are also easily distinguished from $T$. myrakeenae. The tropical T. wellsi Marcus, 1961 (b), is pink and white, and the shapes of the teeth are different (cf. Marcus \& Marcus, 1967: 100, fig. 130), and T. bayeri Marcus \& Marcus, 1967, has an opaque white diffuse network over its dorsum. Tritonia nilsodhneri Marcus, 1983, is rose-pink; T. manicata Deshayes, 1853 , has red, black or olive-green spots on the dorsum; T. plebeia Johnston, 1828, has white stippling but is darker colored with brown mottling and has more teeth per half row (21-33); $T$. lineata Alder \& Hancock, 1848, has 2 conspicuous longitudinal white lines running lengthwise down the dorsum; although $T$. hombergi Cuvier, 1803, has white splotches, its body shape is different (tubercled dorsum, more prominent bilobed oral veil) and the radula is completely different (denticles on teeth of young specimens and 27-158 teeth in a half row). Thompson \& Brown (1984) give further anatomical characteristics that distinguish these latter 5 species from $T$. myrakeenae. Mrs. Marcus (1983) details the anatomy of other Tritoniidae, none of which are comparable with Tritonia myrakeenae.

Etymology: This new species is named in honor of the distinguished malacologist, Dr. A. Myra Keen (1905-1986), colleague and friend, who included nudibranchs in Sea Shells of Tropical West America, second edition (this was the first major review of all known nudibranchs and other opisthobranchs from the Panamic marine faunal province). Her persistent scholar- 
ship and encouragement of research has helped us to know (and hopefully to protect) the mollusks of western North America.

\section{Acknowledgments}

Field work was partially supported by a grant (to the senior author) from Have Mule Will Travel (Alpine, California), and with the cooperation of the Escuela Superior de Ciencias Marinas, Universidad Autonoma de Baja California, Ensenada (Guadalupe Ballesteros, Director).

We especially thank Jesus Pineda for collecting assistance in Ensenada, and the Cedros Island Have Mule Will Travel research expedition team (including Miss Soa Tsung) of December 1985-January 1986.

The illustration of the living animal of Tritonia myrakeenae (Figure 1) was drawn by Señorita Clara Yañes.

\section{LITERATURE CITED}

Behrens, D. W. 1980. Pacific coast nudibranchs: a guide to the opisthobranchs of the northeastern Pacific. Sea Challengers, Los Osos, $112 \mathrm{pp}$. 1982. Sakuraeolis enosimensis (Baba, 1930) (Nudibranchia: Aeolidacea) in San Francisco Bay. Veliger 24(4):359-363.

1984. Notes on the tergipedid nudibranchs of the northeastern Pacific with a description of a new species. Veliger 27(1):65-71.

Bertsch, H. 1981. Rectification of the generic placement of Sclerodoris tanya (Marcus, 1971), comb. nov., a nudi- branch from southern California, with a range extension to the Gulf of California, Mexico. Veliger 23(3):217-220.

Bertsch, H., and T. Gosliner. 1984. Tritonia pickensi (Nudibranchia: Tritoniidae) from Baja California, Mexico. Shells and Sea Life 16(9):138-139.

Bertsch, H., and S. Johnson. 1981. Hawaiian mudibranchs. Honolulu, Oriental Publ. Co., 112 pp.

Gosliner, T. M. 1981. A new species of tergipedid nudibranch from the coast of California. Jour. Moll. Studies 47:200-205.

Gosliner, T. M., and S. V. Millen. 1984. Records of Cuthona pustulata (Alder \& Hancock, 1854) from the Canadian Pacific. Veliger 26(3):183-187.

Keen, A. M. 1971. Sea shells of tropical west America, second edition. Stanford, California, Stanford University Press, 1064 pp.

MacFarland, F. M. 1966. Studies of opisthobranchiate mollusks of the Pacific coast of North America. Mem. Calif. Acad. Sci. 6:546 pp.

Marcus, Er. 1961 a. Opisthobranch mollusks from California. Veliger 3 (Suppl.):1-85.

1961 b. Opisthobranchia from North Carolina. Jour. Elisha Mitchell Scient. Soc. 77:141-151.

Marcus, Ev. du Bois Reymond. 1983. The western Atlantic Tritoniidae. Bolm. Zool. Univ. S. Paulo 6:177-214.

Marcus, Er. and Marcus, Ev. 1967. American Opisthobranch Mollusks. Studies Trop. Oceanogr. 6:1-256.

McDonald, G. 1983. A review of the nudibranchs of the California coast. Malacologia 24(1-2):114-276.

Millen, S. V. 1985. The nudibranch genera Onchidoris and Diaphorodoris (Mollusca, Opisthobranchia) in the northeastern Pacific. Veliger 28(1):80-93.

Stearns, R. E. C. 1873. Descriptions of a new genus and two new species of nudibranchiate mollusks from the coast of California. Proc. Calif. Acad. Sci. 5:77-78.

Thompson, T. E., and G. H. Brown. 1984. Biology of Opisthobranch Molluses, Volume II. London, The Ray Society, 229 pp.

\title{
UNIONIDAE OF THE UPPER CONNECTICUT RIVER, A VANISHING RESOURCE ${ }^{1}$
}

\author{
Arthur H. Clarke \\ ECOSEARCH, Inc., 325 East Bayview \\ Portland, TX 78374
}

\section{Introduction}

It was my good fortune to meet William J. Clench in the winter of 1949-50, shortly after having become irrevocably committed to shell collecting. His personality was so enthusiastic and friendly and the Mollusk Department was so

'In memory of my good friend and teacher, William J. Clench. impressive that I soon made frequent trips to the Museum of Comparative Zoology at Harvard, known familiarly as the "MCZ", and later became a Saturday volunteer. It was not long after that I resolved to seek a career in malacology. I shall always be grateful to Bill Clench and to Ruth Turner for the inspiration to make that decision and for their numerous acts of kindness since that time. 


\section{$2 \mathrm{BHL}$ Biodiversity Heritage Library}

1986. "A new species of Tritonia (Nudibranchia) from southern California and Baja California." The Nautilus 100, 46-49. https://doi.org/10.5962/bhl.part.26492.

View This Item Online: $\underline{\text { https://www.biodiversitylibrary.org/item/34233 }}$

DOI: https://doi.org/10.5962/bhl.part.26492

Permalink: https://www.biodiversitylibrary.org/partpdf/26492

\section{Holding Institution}

MBLWHOI Library

\section{Sponsored by}

MBLWHOI Library

\section{Copyright \& Reuse}

Copyright Status: In copyright. Digitized with the permission of the rights holder.

Rights Holder: Bailey-Matthews National Shell Museum

License: http://creativecommons.org/licenses/by-nc-sa/3.0/

Rights: https://biodiversitylibrary.org/permissions

This document was created from content at the Biodiversity Heritage Library, the world's largest open access digital library for biodiversity literature and archives. Visit BHL at https://www.biodiversitylibrary.org. 